\title{
Strategi Calon Legislatif Partai Gerindra dalam Memenangkan Pemilu Legislatif Tahun 2019 di Kota Padang
}

\author{
Palvi Herlina Syahda, Al Rafni \\ Prodi Pendidikan Pancasila dan Kewarganegaraan \\ FIS Universitas Negeri Padang \\ E-mail: alrafni68@gmail.com
}

\section{ABSTRAK}

Penelitian ini membahas strategi yang digunakan calon legislatif partai Gerindra dalam memenangkan pemilu legislatif tahun 2019 di kota Padang serta faktor penghambat dan pendukung implementasi strategi politik oleh calon legislatif partai Gerindra dalam memenangkan pemilu legislatif tahun 2019 di Kota Padang. Jenis penelitian kualitatif dengan metode penelitian naturalistik. Dilakukan dikantor DPC Partai Gerindra Kota Padang dan kantor DPRD Kota Padang. Metode purposive sampling digunakan dalam pemilihan informan. Teknik analisis data yang peneliti digunakan adalah reduksi data, penyajian data, dan penarikan kesimpulan dan verifikasi. Kemudian uji kreadibilitas data dilakukan dengan triangulasi sumber. Teknik pengumpulan data yang digunakan peneliti adalah pengumpulan data dengan cara observasi, wawancara dan dokumentasi. Strategi yang diterapkan melaluipenyusunan perencanaan berupa pendekatan pada masyarakat sudah jauh sebelum mencalonkan diri dengan cara mendatangi langsung kelapangan bersama program kerja nyata yang betul-betul dirasakan masyarakat dan melakukan pemetaan wilayah kampanye. Dalam menjalankan strategi ada beberapa faktor pendukung berupa elektabilitas caleg yang didukung oleh setting politik yang disebut dengan Prabowo-Sandi Effect dan adanya faktor penghambat berupa kampanye hitam, politik uang, dan beredarnya isu politik. Semakin efektif strategi yang diterapkan maka akan semakin baik citra caleg partai politik dimasyarakat.

Kata Kunci: strategi, calon legislatif, Prabowo-Sandi effect

\section{ABSTRACT}

This research discusses the strategies used by the Gerindra party legislative candidates in winning the 2019 legislative elections in the city of Padang as well as the inhibiting and supporting factors for the implementation of political strategies by the Gerindra party legislative candidates in winning the 2019 legislative elections in Padang City. This type of qualitative research with naturalistic research methods. Conducted at the DPC Gerindra Party office in Padang City and the Padang City DPRD office. The purposive sampling method was used in the selection of informants. The data analysis techniques used were data reduction, data presentation, and drawing conclusions and verification. Then the data reliability test was carried out by triangulation of sources. The data collection technique used by researchers is data collection by means of observation, interviews and documentation. The strategy applied through the formulation of planning in the form of an approach to the 
community was long before running for office by going directly to the field with a real work program that was really felt by the community and conducting area mapping. campaign. In carrying out the strategy, there are several supporting factors in the form of candidate electability which is supported by a political setting called the Prabowo-Sandi Effect and the presence of inhibiting factors in the form of black campaigns, money politics, and the circulation of political issues. The more effective the strategy applied, the better the image of political party candidates in the community.

Keywords: strategy, legislative candidates, Prabowo-Sandi Effect

(c) (7) (2) This work is licensed under the Creative Commons Attribution-ShareAlike 4.0 International License. EY SA 02021 by author.

Received: Agt $132020 \quad$ Revised: Sept 162020

\section{PENDAHULUAN}

Pemilihan umum merupakan implikasi dari pelaksanaan kedaulatan rakyat. Masyarakat diberikan kebebasan untuk berpartisipasi secara aktif dalam menggunakan hak pilih mereka tanpa adanya intervensi dari pihak manapun untuk memilih orangorang atau calon-calon yang akan mengisi jabatan-jabatan di pemerintahan seperti pemilihan Presiden, Anggota Legislatif, Kepala Daerah, maupun wakil rakyat lainnya yang duduk di pemerintahan. Berdasarkan pasal 1 ayat (1) UndangUndang Nomor 7 tahun 2017 menyatakan bahwa " Pemilihan Umum yang selanjutnya disebut pemilu adalah sarana kedaulatan rakyat untuk memilih anggota Dewan Perwakilan Rakyat, anggota Dewan perwakilan Daerah, Presiden dan Wakil presiden, dan untuk memilih anggota Dewan Perwakilan Rakyat Daerah, yang dilaksanakan secara langsung, umum, bebas, rahasia, jujur, dan adil dalam Negara Kesatuan Republik Indonesia berdasarkan Pancasila dan Undang-Undang Dasar Negara Republik Indonesia Tahun 1945."
Dalam Undang-Undang Nomor 7 tahun 2017 dalam pasal 1 ayat (7) disebutkan bahwa penyelenggara Pemilu adalah lembaga yang menyelenggarakan Pemilu yang terdiri atas Komisi pemilihan Umum, Badan Pengawas Pemilu, dan Dewan Kehormatan Penyelenggara Pemilu sebagai satu kesatuan fungsi penyelenggaraan Pemilu untuk memilih anggota DPR, DPD, Presiden dan Wakil Presiden, dan untuk memilih anggota DPRD secara langsung oleh rakyat". Jadi dalam pemilu itu dituntut harus adanya keikutsertaan rakyat karena sejalan dengan pengertian demokrasi yaitu dari rakyat, oleh rakyat, dan untuk rakyat.

Strategi politik menurut Schroder dalam Zainuddin (2014) merupakan strategi yang digunakan untuk mewujudkan cita-cita politik. Dalam pemilu strategi politik perlu digunakan untuk memenangkan persaingan politik. Agar suatu kontestan dapat memenangkan pemilihan umum, calon kandidat harus dapat membuat pemilih berpihak dan memberikan suara kepadanya. Hal ini hanya akan dapat 
dicapai apabila kontestan memperoleh dukungan yang luas dari pemilih. Setiap peserta pemilu yang diusung oleh partai politiknya akan berupaya menerapkan strategi yang baik dalam mempengaruhi masyarakat sebagai pemilih. Pemilihan strategi yang tepat sangatlah penting dilakukan agar pemenangan bisa efektif dan efisien.

Demikian pula strategi yang dilakukan oleh calon legislatif Partai Gerindra dalam memenangkan pemilu legislatif pada tahun 2019 di Provinsi Sumatera Barat. Partai Gerindra keluar sebagai pemenang pada Pileg untuk daerah Sumatera Barat periode 20192024 yang berhasil memperoleh 14 kursi di DPRD Sumatera Barat dari 8 daerah pemilihan yang ada di Sumbar dari $81 \%$ partisipasi pemilih dengan total 3.7 juta suara. Begitu juga yang dilakukan Partai Gerindra dalam memenangkan pemilu legislatif untuk kota Padang yang berhasil memperoleh 11 kursi di DPRD kota Padang (topsatu.com diakses pada 3 Juni 2019). Perolehan 11 kursi pada Pileg 2019 di DPRD kota Padang jauh dibandingkan periode sebelumnya pada Pileg 2014 partai Gerindra juga memperoleh 6 kursi di DPRD kota Padang. Namun dengan suara terbanyak sebesar 44.536 suara atau 13,1 \% di kota Padang seperti pada tabel berikut ini:

Tabel 1: Daftar anggota legislatif Gerindra di Kota Padang periode 2019-2024

\begin{tabular}{|l|l|c|c|}
\hline No & \multicolumn{1}{|c|}{ Nama } & $\begin{array}{c}\text { Jumlah } \\
\text { Suara }\end{array}$ & $\begin{array}{c}\text { Daerah } \\
\text { Pemilihan }\end{array}$ \\
\hline 1 & Syafrial Kani & 7,091 & Dapil 2 \\
\hline 2 & Maztilizal Aye & 4.964 & Dapil 5 \\
\hline 3 & Donal Ardi & 4.218 & Dapil 2 \\
\hline 4 & Delma Putra & 4.186 & Dapil 1 \\
\hline 5 & Elly Triansyah, SE. Akh & 4.162 & Dapil 3 \\
\hline 6 & Dewi Susanti & 3.602 & Dapil 3 \\
\hline 7 & Amran Tono & 3.564 & Dapil 3 \\
\hline 8 & Muzni Zeni,SH & 2.338 & Dapil 2 \\
\hline 9 & Boby Rustam & 2.057 & Dapil 4 \\
\hline 10 & Budi S, SH & 1.811 & Dapil 5 \\
\hline 11 & Manufer Putra Firdaus & 1.786 & Dapil 1 \\
\hline
\end{tabular}

Sumber: $\quad$ http://kota-padang.kpu.go.id (diakses pada 23 juli 2019)

Beberapa penelitian mengenai strategi pemenangan calon anggota legislatif telah banyak dilakukan yang memberikan gambaran bahwa terdapat strategi yang digunakan untuk memenangkan pemilu. Diantaranya, strategi kampanye politik calon anggota legislatif incumbent DPRD di Kabupaten MukoMuko. Jurnal yang ditulis oleh Yanto (2014) menjelaskan bahwa penelitian ini menggambarkan atau mendeskripsikan tentang strategi yang digunakan dalam pembentukan tim kampanye caleg incumbent dengan cara menjaga konsolidasi hubungan keluarga, organisasi-organisasi dan kelompok-kelompok masyarakat serta tokoh-tokoh masyarakat yang berpengaruh.

Kemudian penelitian tentang Strategi Political Marketing DPD Partai Gerindra Sumbar dalam Pileg 2014 di Provinsi Sumatera Barat yang ditulis oleh Ria Adriani (2015) menjelaskan bahwa DPD Partai gerindra Sumbar melakukan strategi political marketing melalui aktifitas politik dengan memasarkan program dan kandidat sebagai produk partai melalui penggunaan media. Hal inilah yang membedakan penelitian ini dengan penelitian sebelumnya. Penelitian ini membahas tentang strategi yang digunakan calon legislatif Gerindra dalam memenangkan pemilu legislatif tahun 2019 di kota Padang serta faktor penghambat dan pendukung implementasi strategi politik oleh calon legislatif partai Gerindra dalam memenangkan pemilu legislatif tahun 2019 di Kota Padang. 


\section{METODE PENELITIAN}

Jenis penelitian ini adalah penelitian kualitatif dengan metode penelitian naturalistik karena penelitiannya dilakukan pada kondisi yang alamiah (natural setting). Penelitian ini dilakukan dikantor DPC Partai Gerindra Kota Padang kantor DPRD Kota Padang. Informan adalah orang yang dimanfaatkan untuk memberikan informasi tentang kondisi dan situasi penelitian. Metode perposive sampling digunakan dalam pemilihan informan pada penelitian ini yaitu Teknik penentuan sampel dengan pertimbangan tertentu. Sumber data lain yaitu melalui bukubuku, jurnal, peraturan perundangundangan, dan media massa.

Teknik pengumpulan data yang digunakan peneliti adalah melalui observasi, wawancara dan dokumentasi. Adanya batasan dan ruang lingkup dalam observasi supaya jawabannya tidak melebar. Melalui wawancara, informan mengatakan adanya strategi yang digunakan untuk pemenangan calon legislatif Gerindra dalam memenangkan Pileg 2019 di Kota Padang. Kemudian untuk mendapatkan data yang lebih akurat peneliti melakukan wawancara dengan menggunakan pedoman wawancara. Teknik analisis data yang peneliti digunakan adalah reduksi data, penyajian data, dan penarikan kesimpulan dan verivikasi. Kemudian uji kreadibilitas data atau kepercayaan terhadap data hasil penelitian dilakukan antara lain dengan trianggulasi sumber. Dengan cara mengecek data yang telah diperoleh melalui beberapa sumber.

\section{HASIL DAN PEMBAHASAN}

Bagi setiap partai politik,
strategi dalam mengikuti dan memenangkan Pemilu adalah sesuatu hal yang harus dimiliki dan merupakan bagian dari grand strategi partai, yaitu strategi Politik. Sebuah bentuk strategi politik yang khusus adalah strategi pemilihan umum, yang diutamakan disini adalah memperoleh kekuasaan dan sebanyak mungkin pengaruh dengan cara memperoleh hasil yang baik dalam pemilu. Sehingga politik dapat diwujudkan dalam suatu perubahan dalam masyarakat. Ralph M. Goldman (SP. Varma, 2003:408) mengatakan strategi merupakan suatu keseluruhan rencana bertindak yang dipakai seorang pemain dalam rangka mencapai suatu hasil atau serangkaian hasil yang diinginkan dalam keadaan yang merugikan.

Dalam masyarakat demokratis, pemilu yang demokratis dalam berbagai bentuk dan kemungkinannya dilaksanakan sebelum seseorang dapat mengambil alih kekuasaan dan mendapat kemungkinan untuk memiliki pengaruh. Oleh karena itu, pihak yang bersangkutan harus memperoleh suara yang cukup dalam Pemilu agar ia dapat memiliki pengaruh. Oleh sebab itu, pemilih harus direncanakan dengan hati-hati dan untuk itu dibutuhkan apa yang disebut dengan 'Strategi'. Strategi pemilu untuk memperoleh kekuasaan seringkali dipandang sebagai hal yang buruk, bahkan oleh partai yang bersangkutan. Tetapi tanpa adanya kekuasaan ini bagi calon atau partai terkait, konsep politik lain yang bukan merupakan konsep politik merekalah yang akan diterapkan. Padahal konsep politik lain itu menurut pandangan para politisi, suatu partai biasanya lebih buruk daripada konsep mereka sendiri. 
Menurut Peter Schorder dalam Mufti (2013) strategi terbagi 2 yaitu:

\section{Strategi Ofensif}

Strategi ofensif adalah strategi yang memperluas pasar dan menembus pasar. Dalam strategi ofensif yang digunakan untuk mengimplementasikan politik, yang harus dijual adalah perbedaan terhadap keadaan yang berlaku saat itu serta keuntungan-keuntungan yang dapat diharapkan. Strategi ini sangat dibutuhkan, misalnya apabila suatu partai ingin menambah atau meningkatkan jumlah massa pemilihnya. Dalam hal ini harus ada banyak orang yang memiliki pandangan dan pemikiran yang positif terhadap partai tersebut, sehingga nantinya kampanye yang akan dilaksanakan partai politik akan dapat berhasil.

\section{a) Kampanye Pemilihan umum}

Strategi perluasan pasar yang ofensif bertujuan untuk membentuk kelompok pemilih baru disamping para pemilih yang telah ada. Oleh sebab itu, harus ada penawaran yang lebih baik bagi para pemilih yang selama ini memilih partai pesaing. Strategi semacam ini perlu dipersiapkan melalui sebuah kampanye, untuk menjelaskan kepada publik tentang penawaran baru dan penawaran mana saja yang lebih baik dibandingkan partai lainnya.

b) Dalam Implementasi Politik

Dalam hal ini keuntungan yang dihasilkan politik baru harus lebih diperhatikan. Untuk itu politik harus dijelaskan secara jelas. Dalam hal ini pihak eksekutif sering kali bertindak salah karena keuntungan yang ditawarkan tidak dirumuskan secara jelassehingga tidak dapat dimengerti warga. Sebelum pelaksanaannya perlu dilakukan hubungan kemasyarakatan yang baik untuk menghindari diskriminasi sewaktu-waktu.

c) Strategi Menembus Pasar

Strategi ini menggali potensi yang telah ada secara optimal. Contohnya adalah pemasaran program-program yang dimiliki secara lebih baik dan peningkatan intensitas keselarasan antara program dan individu, contohnya memperbesar tekanan terhadap kelompokkelompok target.

\section{Strategi defensif}

Muncul apabila partai pemerintahan atau koalisi pemerintahan yang terdiri atas beberapa partai yang ingin mempertahankan mayoritasnya dan membawa keuntungan sebanyak mungkin.

a. Strategi Mempertahankan pasar Ini merupakan suatu strategi yang khas untuk mempertahankan mayoritas pemerintah. Dalam kasus semacam ini, partai akan memelihara pemilih tetap mereka, dan memperkuat pemahaman para pemilih musiman mereka sebelumnya pada situasi yang berlangsung. Partai yang ingin mempertahankan pasar, akan mengambil sikap yang bertentangan dengan partai-partai yang menerapkan strategi ofensif. Dalam hubungannya dengan aliansi, partai-partai yang menerapkan strategi defensif menjalankan sebuah pemeliharaan secara intensif terhadap multipikator yang ada serta menawarkan insentif kepada mereka. Data-data tentang keberhaasilan yang diperoleh disebarluaskan ke lingkungan sekitar. Investigasi terutama dilakukan di bidang kehumasan. Dalam organisasi, proses semakin dipermudah, rutinitas dikembangkan dan dengan demikian pengeluaran ditekan. 
Faktor-Faktor Pendukung Dan Penghambat Implementasi Strategi Politik oleh Calon Legislatif Partai Gerindra Dalam Memenangkan Pemilu Legislatif Tahun 2019 Di Kota Padang

\section{Faktor pendukung}

Dari pernyataan yang disampaikan masyarakat Kota Padang peneliti bisa melihat bahwa opini masyarakat terkait janji-janji calon Legislatif memang tidak hanya sekedar rumor lagi, hal ini sudah terdoktrin di masyarakat bahwa janji calon legislatif tidak hanya saat kampanye saja. Tidak mudah bagi calon anggota legislatif partai gerindra untuk memghilangkan rumor atau issue tersebut dan sosok berpengaruh diparotai tersebut juga menjadi daya tarik yang cukup mempengaruhi perolehan suara dan menarik simpati masyarakat Kota Padang. Beberapa penelitian mengenai strategi pemenangan calon anggota legislatif memberikan gambaran bahwa ada strategi yang digunakan untuk memenangkan pemilu. Menjelang pemilu tentu ada strategi yang dipersiapkan partai politik untuk memenangkan calon anggota legislatifnya.

Selain, Kepercayaan masyarakat terhadap calon legislatif partai gerindra dalam memenangkan pemilu legislative tahun 2019. Penulis juga menemukan strategi khusus yang dilakukan oleh calon legislatif partai Gerindra Kota Padang dalam memenangkan pemilu legislatif tahun 2019 dengan setting politik yang kental dengan sebutan Prabowo-Sandi Effect. Para caleg Partai Gerindra dalam pemilu legislatif tahun 2019 di kota Padang dilakukan melalui pendekatan kepada kelompok-kelompok masyarakat dengan menyampaikan program dan didukung oleh PrabowoSandi Effect. Dengan adanya PrabowoSandi Effect ini sangat mempengaruhi perolehan suara bagi caleg Partai Gerindra dalam menarik perhatian masyarakat.

\section{Faktor penghambat}

Dalam jurnal Halimur Rosyid (2019) berdasarkan temuan dan fakta yang diperoleh hambatan yang dihadapi oleh caleg diantaranya adalah money politic, black campaign, apatisme politic, dan tumpang tindih garapan antar sesama caleg di basis pilihan yang sama. Kerasnya persaingan antar Caleg baik itu dari internal partai maupun dari partai yang berbeda, sehingga memaksa Caleg untuk melakukan berbagai macam bentuk strategi untuk dapat memenangkan kompetisi.

Salah satunya dengan menggunakan money politic. Caleg juga dihadapkan pada perebutan suara pemilih yang kemungkinan sama. Artinya dalam satu wilayah tertentu, sering terdapat caleg dari partai yang sama untuk berebut mendapatkan dukungan pemilih di wilayah itu, sehingga kemungkinan untuk melakukan black campaign menjadi sangat besar. keterbukaan pemilih untuk menjadi sasaran mobilisasi. Pemilih kebanyakan belum memiliki pilihan, bahkan cenderung masyarakat apatis terhadap partai politik (apatisme politic). Keempat, posisi pemilih yang memang sudah berada pada berbagai tekanan untuk memilih banyaknya Caleg, dengan banyaknya jumlah Caleg, seorang pemilih dapat mengalami keresahan yang luar biasa. 


\section{KESIMPULAN}

Berdasarkan penelitian yang telah peneliti lakukan, peneliti menemukan bahwa salah satu faktor kemenangan calon legislatif partai Gerindra tidak terlepas dari dukungan yang diberikan oleh partai. Jika dibandingkan dengan calon legislatif lainnya caleg partai Gerindra mempunyai keunggulan yang tidak dimiliki calon legislatif lainnya, yaitu pada strategi yang diterapkan terlihat bahwa caleg partai Gerindra melakukan pendekatan pada masyarakat sudah jauh sebelum mencalonkan diri dengan cara mendatangi langsung kelapangan atau door to door dan program kerjanya yang nyata dirasakan masyarakat sampai

\section{DAFTAR PUSTAKA}

Ria, A. (2015). Strategi Political Marketing Dpd Partai Gerindra Sumbar Dalam Pemilu Legislatif 2014 Di Provinsi Sumatera Barat (Doctoral dissertation, UNIVERSITAS ANDALAS)

Darwandi Hamid. 2013. Berpolitik dengan biaya murah .yogyakarta : thafa media

Rosyid, H. (2019). Strategi Pemenangan Caleg Partai Gerindra pada Pemilihan Umum Legislatif 2014. Madani Jurnal Politik Dan Sosial Kemasyarakatan, 11(1), 60-73.

Mufti,Muslim,2013. Teori- teori Politik. Bandung: Pustaka Setia

Sugiono. 2017. Metode Penelitian Kualitatif Dan R\&D. Alfabeta: Bandung

Varma SP. 2003. Teori Politik Modern. Raja Grafindo Persada : Jakarta

Yanto, Y. Strategi Kampanye Politik Calon Anggota Legislatif Incumbent Dewan Perwakilan saat ini. Strategi tersebut di rangkum dan direncanakan sesuai dengan target yang akan dicapai oleh Partai Gerindra. Semakin efektif strategi yang diterapkan maka semakin baik pula citra politik calon Legislatif tersebut dan secara tidak langsung masyarakat sebagai pemilih akan memilih Calon Legislatif yang menurut mereka memiliki strategi yang efektif. Strategi khusus yang dilakukan oleh calon legislatif partai Gerindra Kota Padang dalam memenangkan pemilu legislatif tahun 2019 dengan setting politik yang kental dengan sebutan Prabowo-Sandi Effect. Dengan adanya Prabowo-Sandi Effect ini sangat mempengaruhi perolehan suara bagi caleg Partai Gerindra dalam menarik perhatian masyarakat.

Rakyat Daerah Dalam Menghadapi Pemilu Legislatif 2014 (Studi Kasus Partai Golkar Di Kabupaten Mukomuko). Professional: Jurnal Komunikasi dan Administrasi Publik, 1(2), 161547.

Nurtakwa, N. (2017). Strategi Politik Kader Partai Amanat Nasional pada Pemilu Legislatif Tahun 2014 di Kabupaten Enrekang (Doctoral dissertation, Universitas Islam Negeri Alauddin Makassar).

Undang-Undang Nomor 7 Tahun 2017 tentang Pemilihan Umum

https://www.google.com/amp/s/w ww.topsatu.com/-inikomposisi-dprd-padang-20192024/amp/ (diakses pada 3 Juni 2019)

http:/ / kota-padang.kpu.go.id (diakses pada 23 juli 2019) 